\title{
In Vitro Antidiabetic and Anti-oxidant Activities of Methanol Extract of Tinospora Sinensis
}

\author{
Anindita Banerjee ${ }^{1}$, Bithin Maji ${ }^{1}$, Sandip Mukherjee ${ }^{1}$, Kausik Chaudhuri ${ }^{2}$, Tapan Seal ${ }^{2 *}$ \\ ${ }^{1}$ Department of Physiology, Serampore College, Hooghly, West Bengal, India. \\ ${ }^{2}$ Plant Chemistry Department, Botanical Survey of India, Howrah, India.
}

\section{ARTICLE INFO}

Article history:

Received on: 30/12/2016

Accepted on: 26/02/2017

Available online: 19/06/2017

Key words:

Tinospora sinensis, Methanol

extract, Antioxidant activities,

$\alpha$-amylase inhibitory activity,

$\alpha$-glucosidase inhibitory activity.

\begin{abstract}
In the present study the methanol extracts of Tinospora sinensis Lour (Merr.) was studied for alpha $(\alpha)$ amylase and alpha $(\alpha)$-glucosidase inhibition using an in vitro model. The plant extracts were also examined for its antioxidant activities by using free radical 1,1-diphenyl-2-picryl hydrazyl (DPPH) scavenging method, ABTS radical scavenging ability, reducing power capacity, estimation of total phenolic content, flavonoid content and flavonol content. The study revealed that the different concentrations of the extract possessed a very good amount of total phenolics, flavonoid and flavonol and exhibit potent radical scavenging activity using DPPH and ABTS as substrate. The methanol extract exhibited significant $\alpha$-amylase and $\alpha$-glucosidase inhibitory activities with an $\mathrm{IC}_{50}$ value $0.75 \mu \mathrm{g}$ and $0.80 \mu \mathrm{g}$ dry extract respectively and well compared with standard acarbose drug. Thus, it could be concluded that due the presence of antioxidant components the plant extract have well prospective for the management of hyperglycemia, diabetes and the related condition of oxidative stress. This knowledge will be useful in finding more potent antidiabetic principle from the natural resources for the clinical development of antidiabetic therapeutics.
\end{abstract}

\section{INTRODUCTION}

Diabetes mellitus is an important chronic metabolic disorder that affects the metabolism of carbohydrate, fat and protein. It includes a group of metabolic diseases characterized by hyperglycemia, in which blood sugar levels are elevated either because the pancreas do not produce enough insulin or cells of the body do not respond properly to the insulin produced. The effects of diabetes mellitus include long-term complications include heart disease, stroke, dysfunction and failure of various organs [1]. There are three forms of diabetes. The three main types of diabetes are type 1, type 2 , and gestational diabetes. Both women and men can develop diabetes at any age. The only therapy of type 1 diabetes is the substitution of insulin. Many and diverse therapeutic strategies for the treatment of type 2 diabetes are known. The conventional treatments for diabetes include the reduction of the demand for insulin, stimulation of endogenous insulin secretion, enhancement of the action of insulin at the

* Corresponding Author

Tapan Seal, Plant Chemistry Department, Botanical Survey of India,

Howrah, India. E-mail: kaktapan65 @ yahoo.co.in target tissues and the inhibition of degradation of oligo- and disaccharides [2, 3]. One group of drugs introduced in the management of type 2 diabetes is represented by the inhibitors of $\alpha$-glucosidase. The enzymes summarized as $\alpha$-glucosidase are responsible for the breakdown of oligo- and/or disaccharides to monosaccharides. The inhibitory action of these enzymes leads to a decrease of blood glucose level, because the monosaccharides are the form of carbohydrates which is absorbed through the mucosal border in the small intestine. Another effective method to control diabetes is to inhibit the activity of $\alpha$-amylase enzyme which is responsible for the collapse of starch to more simple sugars (dextrin, maltotriose, maltose and glucose) [4]. This is contributed by $\alpha$-amylase inhibitors, which delays the glucose absorption rate thereby maintaining the serum blood glucose in hyperglycemic individuals [5]. Some inhibitors currently in clinical use are acarbose and miglitol which inhibit glycosidases such as $\alpha$-glucosidase and $\alpha$-amylase while others such as and voglibose inhibit $\alpha$-glucosidase. However, many of these synthetic hypoglycemic agents have their limitations, are non-specific, produce serious side effects and fail to elevate diabetic complications. The main side effects of these inhibitors are gastrointestinal viz., bloating, abdominal discomfort, diarrhea and flatulence [6]. 
Recently herbal medicines are getting more importance in the treatment of diabetes as they are free from side effects and less expensive when compared to synthetic hypoglycemic agents [7-8]. Phytochemical constituents like saponin, phenols, flavonoids etc studied in various plants such as Proteus vulgaris, Euphorbia hirta, Cassia glauca showed potential $\alpha$-amylase inhibitors [9]. The role of medicinal plants in disease prevention is attributed to its antioxidant properties due to the presence of bioactive constituents [10]. Tinospora sinensis (Lour.) Merr belongs to the family Menispermaceae, and the stem of the plant is used as medicine. The plant grows wild in most parts of India, both in forests and plains. The plant is reported to be used for fumigation in piles and ulcerated wounds, and for the preparation of medicated baths for liver-complaints. The boiled roots are given in fever. Fresh leaves and stems are used in chronic rheumatism and also a muscle relaxant [11]. Thus, in this study, the antioxidant and antidiabetic activities of the methanol extract from the stem of $T$. sinensis were carried out and a relationship between antioxidant and antidiabetic activities was established. To determine the potential of $T$. sinensis stem extract as antidiabetic agents, we investigated the effect of extracts on the $\alpha$-glucosidase and $\alpha$-amylase inhibitory activities.

\section{MATERIALS AND METHODS}

\subsection{Plant materials}

The stem of Tinospora sinensis was collected from Hooghly district West Bengal, India and authenticated from Botanical Survey of India, Howrah. The voucher specimens were preserved in our department under registry no $\mathrm{PHYSIOL/BM/AB}$ 001. The plant parts were shed-dried, pulverized and stored in an airtight container for further extraction.

\subsection{Chemicals}

Alpha $(\alpha)$-Glucosidase, porcine pancreas alpha $(\alpha)$ amylase, $\quad p$-nitrophenyl- $\alpha$-D-glucopyranose $\quad(p$-NPG), 3,5dinitrosalicylic acid (DNS), 1,1-Diphenyl-2-picrylhydrazyl (DPPH), 2,2'-azino-bis(3-ethylbenzothiazoline-6-sulfonic acid) (ABTS), butylated hydroxytoluene (BHT), gallic acid, rutin, quercetin, ascorbic acid and acarbose were purchased from Sigma Chemical Co. (St. Louis, MO, USA). Soluble starch, sodium potassium tartarate, sodium dihydrogen phosphate $\left(\mathrm{NaH}_{2} \mathrm{PO}_{4}\right)$, Disodium hydrogen phosphate $\left(\mathrm{Na}_{2} \mathrm{HPO}_{4}\right)$ sodium chloride, sodium hydroxide, butylated hydroxytoluene (BHT), potassium persulfate, sodium carbonate, Folin-Ciocalteu (FC) reagent, potassium ferricyanide, potassium per sulphate, aluminum chloride, ferric chloride $\left(\mathrm{FeCl}_{3}\right)$ were from Merck Chemical Supplies (Damstadt, Germany). All the chemicals used including the solvents, were of analytical grade.

\subsection{Extraction of plant material}

The air-dried and coarse powdered plant sample of $T$. sinensis (10 g) was extracted with $100 \mathrm{ml}$ methanol by maceration on an orbital shaker with agitation for five days at room temperature. The extracts was filtered and residue was again extracted with same solvent for another five days and filtered. The filtered extracts were combined and concentrated using a rotary evaporator, under reduced pressure at approximately $40^{\circ} \mathrm{C}$ and lyophilized to obtain the powdered extract. The powdered extract were analysed for their $\alpha$-glucosidase and $\alpha$-amylase inhibition assays. The total phenolic, flavonoid and flavonol content, reducing power and their free radical scavenging capacity of the methanol extract of the plant were also investigated.

\subsection{Estimation of total phenolic content}

The amount of total phenolic content of crude extracts was determined according to Folin-Ciocalteu procedure [12]. The tested extracts $(100 \mu \mathrm{l})$ were introduced into test tubes. One $\mathrm{ml}$ of Folin-Ciocalteu reagent and $0.8 \mathrm{ml}$ of sodium carbonate $(7.5 \%)$ were added. The tubes were mixed and allowed to stand for 30 min. Absorption at $765 \mathrm{~nm}$ was measured (UV-visible spectrophotometer Shimadzu UV 1800).

\subsection{Estimation of total flavonoids}

Total flavonoids were estimated using the method of Ordonez et al., 2006 [13]. To $0.5 \mathrm{ml}$ of extracts, $0.5 \mathrm{ml}$ of $2 \%$ $\mathrm{AlCl}_{3}$ ethanol solution was added. After one hour, at room temperature, a yellow color developed, indicated the presence of flavonoids and the absorbance was measured at $420 \mathrm{~nm}$ (UVvisible spectrophotometer Shimadzu UV 1800 ).

\subsection{Estimation of total flavonols}

Total flavonols in the plant extracts was estimated using the method of Kumaran and Karunakaran, 2006 [14]. To $1.0 \mathrm{ml}$ of extracts $1.0 \mathrm{ml}$ of $2 \% \mathrm{AlCl}_{3}$ ethanol and $3.0 \mathrm{ml}(50 \mathrm{~g} / \mathrm{L})$ sodium acetate solutions were added. The absorption at $440 \mathrm{~nm}$ (UVvisible spectrophotometer Shimadzu UV 1800) was read after 2.5 $\mathrm{h}$ at $20^{\circ} \mathrm{C}$ for the estimation of total flavonol content in the plant extract.

\subsection{Measurement of reducing power}

The reducing power of the extracts was determined according to the method of Oyaizu, 1986 [15]. The plant extracts $(100 \mu \mathrm{l})$ was mixed with phosphate buffer $(2.5 \mathrm{ml}, 0.2 \mathrm{M}, p \mathrm{H} 6.6)$ and $1 \%$ potassium ferricyanide $(2.5 \mathrm{ml})$. The mixture was incubated at $50^{\circ} \mathrm{C}$ for $20 \mathrm{~min}$. Aliquots of $10 \%$ trichloroacetic acid $(2.5 \mathrm{ml})$ were added to the mixture, which was then centrifuged at $3000 \mathrm{rpm}$ for $10 \mathrm{~min}$.

The upper layer of the solution $(2.5 \mathrm{ml})$ was mixed with distilled water $(2.5 \mathrm{ml})$ and a freshly prepared ferric chloride solution $(0.5 \mathrm{ml}, 0.1 \%)$. The absorbance was measured at $700 \mathrm{~nm}$ and reducing power is determined.

\subsection{Determination of DPPH free radical scavenging activity}

The free radical scavenging activity of the plant extract and butylated hydroxyl toluene (BHT) as positive control was determined using the stable radical DPPH (1,1-diphenyl-2- 
picrylhydrazyl) [16]. $100 \mu \mathrm{l}$ of the tested extracts were placed in test tubes and $3.9 \mathrm{ml}$ of freshly prepared DPPH solution $(25 \mathrm{mg} \mathrm{L}$ $\left.{ }^{1}\right)$ in methanol was added in each test tube and mixed. 30 min later, the absorbance was measured at $517 \mathrm{~nm}$ (UV-visible spectrophotometer Shimadzu UV 1800). The capability to scavenge the DPPH radical was calculated, using the following equation:

\section{DPPH scavenged $(\%)=\{(\mathrm{Ac}-\mathrm{At}) / \mathrm{Ac}\} \times 100$}

Where $\mathrm{Ac}$ is the absorbance of the control reaction and At is the absorbance in presence of the sample of the extracts. The antioxidant activity of the extract was expressed as $\mathrm{IC}_{50}$. The $\mathrm{IC}_{50}$ value was defined as the concentration in mg of dry material per $\mathrm{ml}(\mathrm{mg} / \mathrm{ml})$ that inhibits the formation of DPPH radicals by $50 \%$. Each value was determined from regression equation.

\subsection{Scavenging activity of ABTS radical cation}

The 2,2'-azino-bis(3-ethylbenzothiazoline-6-sulfonic acid) (ABTS) radical cation $\left(\mathrm{ABTS}^{++}\right)$-scavenging activity was measured according to the method described by Re et al. [17]. ABTS was dissolved in water to a $7 \mathrm{mM}$ concentration. The ABTS radicals were produced by adding $2.45 \mathrm{mM}$ potassium persulphate (final concentration). The completion of radical generation was obtained in the dark at room temperature for $12-16 \mathrm{~h}$. This solution was then diluted with ethanol to adjust its absorbance at $734 \mathrm{~nm}$ to $0.70 \pm 0.02$. To determine the scavenging activity, $1 \mathrm{ml}$ of diluted $\mathrm{ABTS}^{+}$solution was added to $20,40 \& 80 \mu \mathrm{l}$ of plant extracts, and the absorbance at $734 \mathrm{~nm}$ was measured 6 min after the initial mixing, using ethanol as the blank. The percentage of inhibition was calculated by the equation:

$$
\text { ABTS scavenged }(\%)=\left(\mathrm{A}_{\text {cont }}-\mathrm{A}_{\text {test }}\right) / \mathrm{A}_{\text {cont }} \times 100
$$

where $A_{c}$ and $A_{s}$ are the absorbencies of the control and of the test sample, respectively. From a plot of concentration against \% inhibition, a linear regression analysis was performed to determine the $\mathrm{IC}_{50}$ value of the sample.

\subsection{In Vitro $\alpha$-amylase inhibitory assay}

A starch solution $(1 \% \mathrm{w} / \mathrm{v})$ was prepared by stirring $1 \mathrm{~g}$ starch in $100 \mathrm{ml}$ of $20 \mathrm{mM}$ of phosphate buffer $(\mathrm{pH}$ 6.9) containing $6.7 \mathrm{mM}$ of sodium chloride. The enzyme solution was prepared by mixing $27.5 \mathrm{mg}$ of porcine pancreatic amylase $\alpha$ amylase (PPA) in $100 \mathrm{ml}$ of $20 \mathrm{mM}$ of phosphate buffer (PBS, $\mathrm{pH}$ 6.9) containing $6.7 \mathrm{mM}$ of sodium chloride. To $100 \mu \mathrm{l}$ of $(2,4,8,10,15 \mu \mathrm{g} / \mathrm{ml})$ plant extracts, $200 \mu \mathrm{l}$ porcine pancreatic amylase was added and the mixture was incubated at $37^{\circ} \mathrm{c}$ for 20 min. To the reaction mixture $100 \mu \mathrm{l}(1 \%)$ starch solution was added and incubated at $37{ }^{\circ} \mathrm{C}$ for $10 \mathrm{~min}$. The reaction was stopped by adding $200 \mu \mathrm{l}$ DNSA (1g of 3,5 di nitro salicylic acid, $30 \mathrm{~g}$ of sodium potassium tartarate and $20 \mathrm{ml}$ of $2 \mathrm{~N}$ sodium hydroxide was added and made up to a final volume of $100 \mathrm{ml}$ with distilled water) and kept it in a boiling water bath for 5 minutes. The reaction mixture diluted with $2.2 \mathrm{ml}$ of water and absorbance was read at $540 \mathrm{~nm}$. For each concentration, blank tubes were prepared by replacing the enzyme solution with $200 \mu \mathrm{L}$ in distilled water.
Control, representing $100 \%$ enzyme activity was prepared in a similar manner, without extract. The experiments were repeated thrice using the same protocol [18].

\subsection{In Vitro $\alpha$-Glucosidase Inhibition Assay}

The inhibition of $\alpha$-glucosidase activity was determined using the modified published method [19]. One $\mathrm{mg}$ of $\alpha$ glucosidase was dissolved in $100 \mathrm{ml}$ of phosphate buffer ( $\mathrm{pH}$ 6.8). To $100 \mu \mathrm{l}$ of $(2,4,8,10,15 \mu \mathrm{g} / \mathrm{ml})$ plant extracts, $200 \mu \mathrm{l} \alpha$ glucosidase were added and the mixture was incubated at $37^{\circ} \mathrm{C}$ for $20 \mathrm{~min}$. To the reaction mixture $100 \mu \mathrm{l} 3 \mathrm{mM} p$-nitrophenyl $\alpha$-Dglucopyranoside ( $p$-NPG) was added and incubated at $37^{\circ} \mathrm{C}$ for 10 min. The reaction was terminated by the addition of $2 \mathrm{ml} \mathrm{Na}_{2} \mathrm{CO}_{3}$ $0.1 \mathrm{M}$ and the $\alpha$-glucosidase activity was determined spectrophotometrically at $405 \mathrm{~nm}$ on spectrophotometer UV-VIS (Shimadzu UV-1800) by measuring the quantity of -nitrophenol released from $p$-NPG. Acarbose was used as positive control of $\alpha$ amylase and $\alpha$-glucosidase inhibitor. The concentration of the extract required to inhibit $50 \%$ of $\alpha$-amylase and $\alpha$-glucosidase activity under the assay conditions was defined as the $\mathrm{IC}_{50}$ value.

\subsection{Method for calculation of $\alpha$-amylase and $\alpha$-glucosidase inhibitory concentration (IC50)}

The concentration of the plant extracts required to scavenge $50 \%$ of the radicals (IC50) was calculated by using the percentage scavenging activities at five different concentrations of the extract. Percentage inhibition (I \%) was calculated by

$$
\mathrm{I} \%=(\mathrm{Ac}-\mathrm{As}) / \mathrm{Ac} X 100 \text {, }
$$

where Ac is the absorbance of the control and As is the absorbance of the sample [20].

Values are presented as mean \pm standard error mean of three replicates. The total phenolic content, flavonoid content, flavonol content, reducing power and $\mathrm{IC}_{50}$ value of each plant material was calculated by using Linear Regression analysis.

\section{RESULTS AND DISCUSSION}

\subsection{Total phenol, flavonoid and flavonol content of the extracts} Polyphenols have been said to be important phytochemicals with significant antioxidant capacities and other important medicinal characteristics. Total phenolic content in the plant extract was determined by the FC method and the calibration curve developed using Gallic acid. A regression equation was obtained from the standard curve and the amount of Gallic acid in the methanol extract of $T$. sinensis was calculated from the regression equation: $y=0.0013 x+0.0498, R^{2}=0.999$ where $y$ was the absorbance and $\mathrm{x}$ was the Gallic acid equivalent $(\mathrm{mg} / \mathrm{g})$.

The investigation showed that the plant under study contain a very good amount of total phenolics $(21.34 \pm 0.25 \mathrm{mg}$ $\mathrm{GAE} / \mathrm{mg}$ plant extracts) which is well compared with the methanol extract of Terminalia arjuna (20.862 mg GAE/g plant extracts) [21]. Total flavonoid contents in the plant extracts were calculated as rutin equivalent $(\mathrm{mg} / \mathrm{g})$ using the equation based on the calibration curve: $\mathrm{y}=0.0182 \mathrm{x}-0.0222, \mathrm{R}^{2}=0.9962$, where $\mathrm{y}$ was 
the absorbance and $\mathrm{x}$ was the rutin equivalent $(\mathrm{mg} / \mathrm{g})$. The flavonol content in the plant was estimated as quercetin $(\mathrm{mg} / \mathrm{g})$ equivalent using the equation based on the calibration curve: $y=$ $0.0049 \mathrm{x}+0.0047, \mathrm{R}^{2}=0.9935$, where $\mathrm{y}$ was the absorbance and $\mathrm{x}$ was the quercetin equivalent $(\mathrm{mg} / \mathrm{g})$. The experimental result showed the presence of appreciable amount of flavonoid $0.35 \pm 0.01 \mathrm{mg} / \mathrm{gm})$ and flavonol $(0.31 \pm 0.01 \mathrm{mg} / \mathrm{gm})$ in the methanol extract of $T$. sinensis. The result of investigation also showed a very good reducing power $(0.52 \pm 0.01 \mathrm{mg} / \mathrm{gm}$ dry extract) with the methanol extract of the plant. The reducing power of the extract was evaluated in ascorbic acid equivalent (AAE) in milligram per gram $(\mathrm{mg} / \mathrm{g})$ of dry extract using the following equation based on the calibration curve: $y=0.0023 x-0.0063, R^{2}$ $=0.9955$ where $\mathrm{y}$ was the absorbance and $\mathrm{x}$ was the ascorbic acid equivalent $(\mathrm{mg} / \mathrm{g})$. It has been established that phenolic, flavonoids and flavonols compounds are regarded as one of the most widespread groups of natural constituents found in the plants which can adsorb and neutralize the free radicals and showed antioxidant activity through scavenging or chelating process [2223]. Thus after determining the total phenol content of the plants, the antioxidant activities of the plants were estimated for their free radical scavenging activity.

\subsection{DPPH free radical scavenging activity}

The evaluation of anti-radical radical scavenging properties of the methanol extract of $T$. sinensis was executed by DPPH radical scavenging assay. The $50 \%$ inhibition of DPPH radical $\left(\mathrm{IC}_{50}\right)$ by the plant extract was determined (Table 1), a lower value would reflect greater antioxidant activity of the sample. DPPH stable free radical method is an easy, rapid and sensitive way to survey the antioxidant activity of a specific compound or plant extracts [24]. The antioxidant effect is proportional to the disappearance of the purple colour of DPPH in test samples. Thus antioxidant molecules can quench DPPH free radicals by providing hydrogen atom or by electron donation and a colourless stable molecule 2,2- diphenyl1-hydrazine is formed and as a result of which the absorbance (at $517 \mathrm{~nm}$ ) of the solution is decreased. Hence the more potent antioxidant, more decrease in absorbance is seen and consequently the $\mathrm{IC}_{50}$ value will be minimum. In the present study the potent radical scavenging activity $\left(\mathrm{IC}_{50}=0.50 \pm\right.$ $0.01 \mathrm{mg} / \mathrm{gm}$ dry ext) was shown by the extract of T. sinensis.

\subsection{Scavenging activity of ABTS radical cation}

The antioxidant activity of the methanol extract of $T$. sinensis using ABTS assay was also carried out. The antioxidant effect is proportional to the disappearance of the colour of ABTS in test samples. Concentration of sample that could scavenge $50 \%$ free radical $\left(\mathrm{IC}_{50}\right)$ was used to determine antioxidant capacity of sample compared to standard. Sample that had $\mathrm{IC}_{50}<50 \mathrm{ppm}$, it was very strong antioxidant, 50-100 ppm strong antioxidant, 101$150 \mathrm{ppm}$ medium antioxidant, while weak antioxidant with $\mathrm{IC}_{50}>$ $150 \mathrm{ppm}$. A strong inhibition was observed $\left(\mathrm{IC}_{50}=0.12 \pm 0.01\right.$ $\mathrm{mg} / \mathrm{gm}$ dry ext.) with the methanol extract of the plant under investigation.

\subsection{In Vitro $\alpha$-amylase inhibitory assay}

In this study the in vitro $\alpha$-amylase inhibitory activities of the methanol extract of $T$. sinensis was investigated. The result of experiment showed that, there was a dose-dependent increase in percentage inhibitory activity against $\alpha$-amylase enzyme. The methanol extract $(2-15 \mu \mathrm{g} / \mathrm{ml})$ of the plant exhibited potent $\alpha$ amylase inhibitory activity in a dose dependent manner. The extract showed inhibitory activity from $3.28 \pm 0.04$ to $20 \pm 0.02 \%$ with an $\mathrm{IC}_{50}$ value of $0.75 \mu \mathrm{g}$ dry extract (Table 2). Acarbose is a standard drug for $\alpha$-amylase inhibitor. Acarbose at a concentration of $(2-15 \mu \mathrm{g} / \mathrm{ml})$ showed $\alpha$-amylase inhibitory activity from $6.99 \pm 0.03$ to $56.17 \pm 0.05 \%$ with an $\mathrm{IC}_{50}$ value 0.32 $\mu \mathrm{g}$ dry extract. A comparison of $\alpha$-amylase inhibitory activity between the standard drug and plant extracts has been depicted in fig. 1. So the plant extract might be used as starch blockers since it prevents or slows the absorption of starch in to the body mainly by blocking the hydrolysis of 1,4-glycosidic linkages of starch and other oligosaccharides into maltose, maltriose and other simple sugars.In our study, the methanol extract of the plant showed maximum $\alpha$ - amylase inhibitory activity $\left(\mathrm{IC}_{50}=0.75 \mu \mathrm{g}\right.$ dry extract) which could be attributed to the presence of polyphenols $(21.34 \pm 0.25 \mathrm{mg} / \mathrm{g})$ and flavonoids $(0.35 \pm 0.31)$ because polyphenols are not only capable of reducing oxidative stress but also of inhibiting carbohydrate hydrolyzing enzymes because of their ability to bind with proteins [1].

Our results are in accordance with the previous study wherein, there is a positive relationship between the total polyphenol and flavonoid content and the ability to inhibit intestinal $\alpha$-glucosidase and pancreatic $\alpha$-amylase [27-28] [25-26].

Table 1: Anti-oxidant activities of the methanol extract of T. sinensis

\begin{tabular}{|c|c|c|c|c|c|c|}
\hline $\begin{array}{c}\text { Name of the } \\
\text { plant }\end{array}$ & $\begin{array}{l}\text { Total phenolic } \\
\text { content }\end{array}$ & $\begin{array}{l}\text { Total flavonoid } \\
\text { content }\end{array}$ & $\begin{array}{l}\text { Total flavonol } \\
\text { content }\end{array}$ & Reducing power & $\begin{array}{l}\text { DPPH Free radical } \\
\text { scavenging ability }\end{array}$ & $\begin{array}{l}\text { ABTS Free radical } \\
\text { scavenging ability }\end{array}$ \\
\hline & $\begin{array}{l}\text { (GAE mg / g dry } \\
\text { extract) }\end{array}$ & $\begin{array}{l}\text { (Rutin equivalent } \\
\mathrm{mg} \text { / g dry extract) }\end{array}$ & $\begin{array}{c}\text { Quercetin } \\
\text { equivalent mg / g } \\
\text { dry extract) }\end{array}$ & $\begin{array}{c}\text { (Ascorbic acid } \\
\text { equivalent mg / g dry } \\
\text { extract) }\end{array}$ & $\left(\mathrm{IC}_{50} \mathrm{mg} / \mathrm{g}\right.$ dry extract $)$ & $\left(\mathrm{IC}_{50} \mathrm{mg} / \mathrm{g}\right.$ dry extract $)$ \\
\hline T. sinensis & $21.34 \pm 0.25$ & $0.35 \pm 0.01$ & $0.31 \pm 0.01$ & $0.52 \pm 0.01$ & $0.50 \pm 0.01$ & $0.12 \pm 0.01$ \\
\hline
\end{tabular}

Each value in the table was obtained by calculating the average of three experiments and data are presented as Mean \pm SEM 
Table 2: In vitro antidiabetic activity of the methanol extract of $T$. sinensis using alpha amylase method and comparison with standard drug acarbose.

\begin{tabular}{|c|c|c|c|c|}
\hline Sl No & $\begin{array}{c}\text { Plant extract/ standard } \\
\text { drug }\end{array}$ & $\begin{array}{c}\text { Concentration } \\
\mu \mathrm{g} / \mathrm{ml}\end{array}$ & $\%$ of Inhibition & $\begin{array}{c}\text { IC }_{50} \\
\mu g \text { dry extract }\end{array}$ \\
\hline \multirow{5}{*}{1} & & 2 & $3.28 \pm 0.04$ & \multirow{5}{*}{0.75} \\
\hline & Methanol extract of & 4 & $5.14 \pm 0.06$ & \\
\hline & T. sinensis & 8 & $10.71 \pm 0.03$ & \\
\hline & & 10 & $14.32 \pm 0.05$ & \\
\hline & & 15 & $20.00 \pm 0.02$ & \\
\hline \multirow{5}{*}{2} & & 2 & $6.99 \pm 0.03$ & \multirow{5}{*}{0.32} \\
\hline & Acarbose & 4 & $11.58 \pm 0.05$ & \\
\hline & & 8 & $26.45 \pm 0.02$ & \\
\hline & & 10 & $41.64 \pm 0.06$ & \\
\hline & & 15 & $56.17 \pm 0.05$ & \\
\hline
\end{tabular}

Each value in the table was obtained by calculating the average of three experiments and data are presented as Mean \pm SEM.

Table 3: In vitro antidiabetic activity of the methanol extract of $T$. sinensis using alpha glucosidase method and comparison with standard drug acarbose.

\begin{tabular}{|c|c|c|c|c|}
\hline SI No & $\begin{array}{c}\text { Plant extract/ standard } \\
\text { drug }\end{array}$ & $\begin{array}{c}\text { Concentration } \\
\mu \mathrm{g} / \mathrm{ml}\end{array}$ & $\%$ of Inhibition & $\begin{array}{c}I_{C_{50}} \\
\mu \mathrm{g} \text { dry extract }\end{array}$ \\
\hline \multirow{5}{*}{1} & \multirow{5}{*}{$\begin{array}{c}\text { Methanol extract of } \\
\text { sinensis }\end{array}$} & 2 & $5.74 \pm 0.09$ & \multirow{5}{*}{0.80} \\
\hline & & 4 & $8.13 \pm 0.07$ & \\
\hline & & 8 & $13.88 \pm 0.12$ & \\
\hline & & 10 & $17.70 \pm 0.09$ & \\
\hline & & 15 & $19.14 \pm 0.11$ & \\
\hline \multirow{5}{*}{2} & \multirow{5}{*}{ Acarbose } & 2 & $29.57 \pm 0.14$ & \multirow{5}{*}{0.46} \\
\hline & & 4 & $31.58 \pm 0.17$ & \\
\hline & & 8 & $34.93 \pm 0.12$ & \\
\hline & & 10 & $38.28 \pm 0.09$ & \\
\hline & & 15 & $41.82 \pm 0.08$ & \\
\hline
\end{tabular}

Each value in the table was obtained by calculating the average of three experiments and data are presented as Mean \pm SEM.

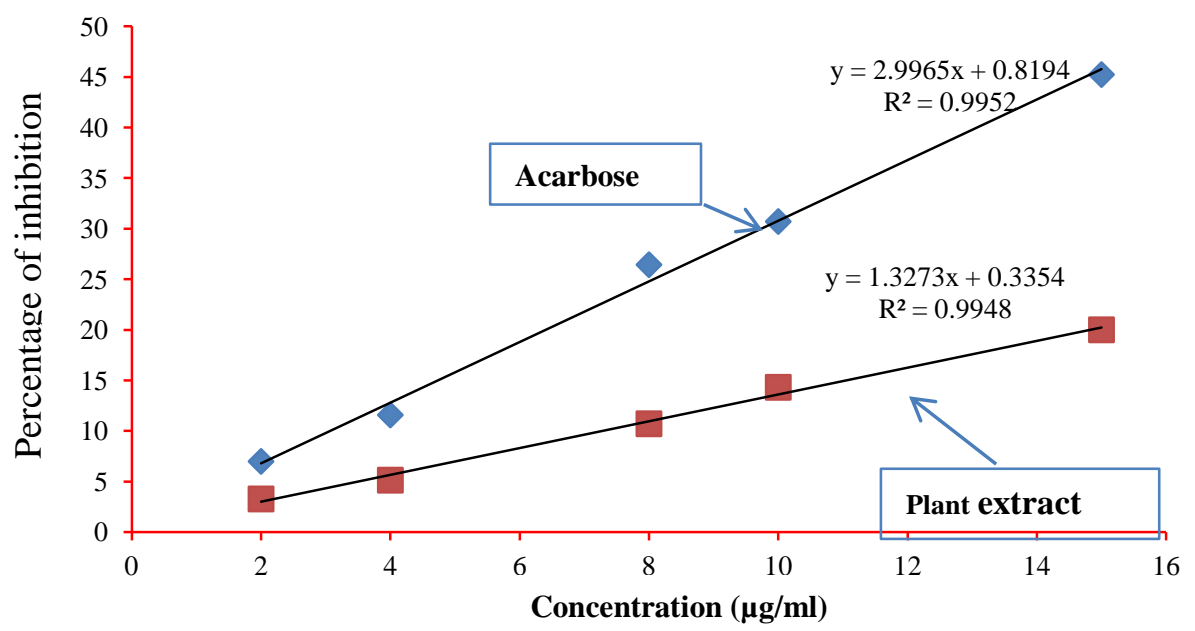

Fig. 1. $\alpha$-Amylase inhibitory activity of Acarbose vs methanol extract of T. sinensis.

\subsection{In Vitro $\alpha$-glucosidase inhibitory assay}

The results of antidiabetic activity using $\alpha$-glucosidase inhibitory assay of the methanol extracts of $T$. sinensis stem are shown in Table 3. The extract revealed a significant inhibitory action of $\alpha$-glucosidase enzyme. The percentage inhibition at 2 $15 \mu \mathrm{g} / \mathrm{ml}$ concentrations of $T$. sinensis extract showed a dose dependent increase in percentage inhibition.

The percentage inhibition varied from $19.62 \%-5.74 \%$ for highest concentration to the lowest concentration. Thus the inhibition of the activity of $\alpha$-glucosidase by $T$. sinensis would delay the degradation of carbohydrate, which would in turn cause a decrease in the absorption of glucose, as a result the reduction of postprandial blood glucose level elevation [30].
A comparison of $\alpha$-glucosidase inhibitory activity between the standard drug and plant extracts has been depicted in fig. 2 .

In this study acarbose was also used as a standard drug for $\alpha$-glucosidase inhibitor. Acarbose at a concentration of (2-15 $\mu \mathrm{g} / \mathrm{ml}$ ) showed $\alpha$-glucosidase inhibitory activity from $29.57 \pm 0.14$ to $41.82 \pm 0.08 \%$ with an $\mathrm{IC}_{50}$ value $0.46 \mu \mathrm{g}$ dry extract. This indicates that the methanolic extract of $T$. sinensis is very potent $\alpha$ amylase and $\alpha$-glucosidase inhibitor in comparison with acarbose. This could be justified that the nature of some extract constituents (phenols, flavonoids saponins, steroids, alkaloids, terpenoids) present in the extract could be responsible as being effective inhibitors of $\alpha$-amylase and $\alpha$-glucosidase. 


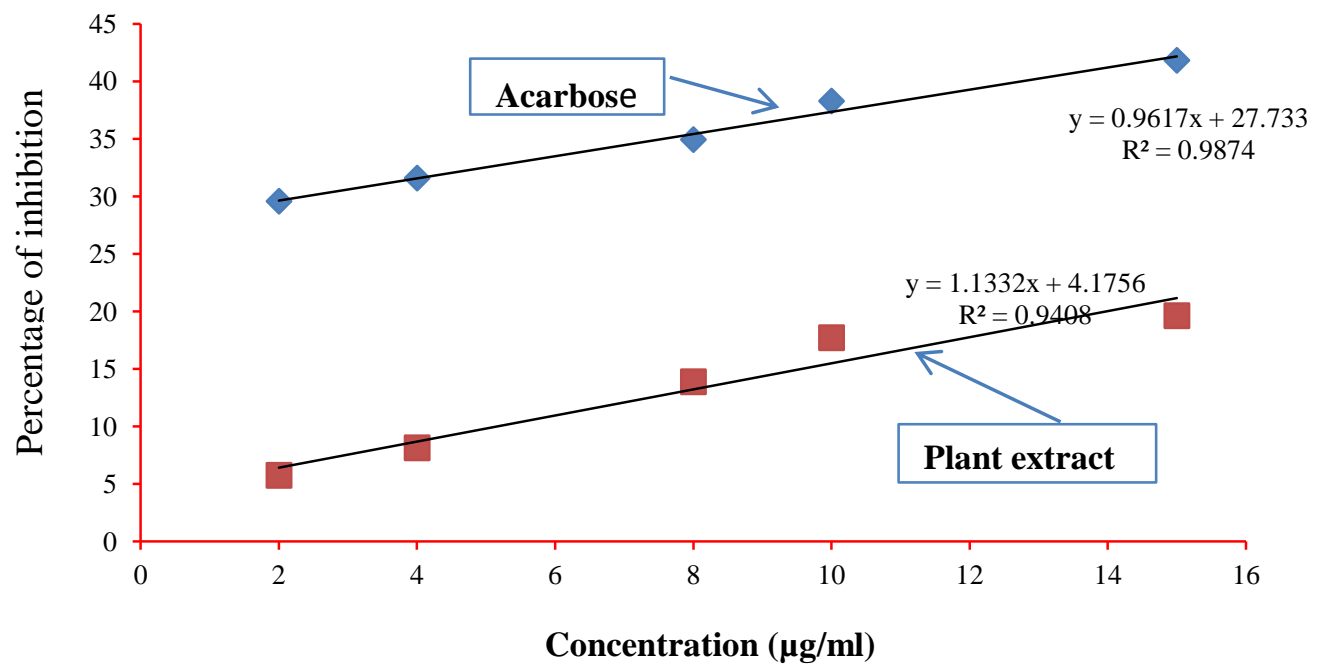

Fig. 2. $\alpha$-Glucosidase inhibitory activity of Acarbose vs methanol extract of T. sinensis.

\section{CONCLUSION}

To investigate the biological activities of $T$. sinensis tuberous stem, the antioxidant and antidiabetic activities of the methanol extract of the plant has been analysed. As a result, we found that the extract of $T$. sinensis have free radical scavenging activity and inhibitory activity against $\alpha$-amylase and $\alpha$ glucosidase and this therapeutic potentiality could be exploited in the management of post prandial hyperglycemia in the treatment of type 2 diabetes mellitus. Although the effects of $T$. sinensis extract have been established in vitro, these results indicate that $T$. sinensis has potential as a crude drug and a dietary health supplement. The plant showed significant enzyme inhibitory activity, so the compound isolation, purification and characterization which are responsible for inhibiting activity, have to be done for the usage of antidiabetic agent. Further studies are also required to elucidate whether the plant have antidiabetic potential by in vivo for corroborating the traditional claim of the plant.

\section{ACKNOWLEDGEMENTS}

Authors of this paper are highly grateful to Dr. P. Singh, Director, Botanical Survey of India, Kolkata, for providing all facilities. We are also thankful to Dr. R. Gogoi, Scientist D, Botanical Survey of India, Howrah for identifying the plant specimens.

6. Conflict of Interests: There are no conflicts of interest.

\section{REFERENCES}

1. Keerthana G, Kalaivani MK, Sumathy A: In-vitro alpha amylase inhibitory and anti-oxidant activities of ethanolic leaf extract of Croton bonplandianum. Asian J Pharm Clin Res, 2013; 6( 4): 32-36.

2. Groop L, Forsblom C, Lehtovirta M: Characterization of the prediabetic state. Am J Hypertens, 1997; 10: 172-180.
3. Perfetti R, Barnett PS, Mathur R, Egan JM: Novel therapeutic strategies for the treatment of type 2 diabetes. Diabetes Metab Rev, 1998; 14: 207-225.

4. Alexander R: Maltodextrins: production, properties and applications.In: Schenk F, Hebeda R (ed.) Starch hydrolysis products; worldwide technology: production and applications, New York, 1992. p. 62-122.

5. Dineshkumar B, Mitra A, Manjunatha.M: A comparative study of alpha amylase inhibitory activities of common antidiabetic plants of Kharagpur 1 block. Int J Green Pharm,. 2010 ; 4: 115-21.

6. Cheng AYY, Fantus IG: Oral antihyperglycemic therapy for type 2 diabetes mellitus. Canadian Medicinal Association Journal, 2005 ; 172(2): 213-226.

7. Grover JK, Yadav S, Vats V: Medicinal plants of India with antidiabetic potential. J Ethnopharmacol., 2002; 81: 81-100.

8. Mukherjee PK, Maiti K, Mukherjee K, Houghton PJ: Leads from Indian medicinal plants with hypoglycemic potentials. J Ethnopharmacol. 2006; 106(1): 1-28.

9. Sunil K, Rashmi Kumar D: Evaluation of anti diabetic activity of Euphorbia hirta Linn. in streptozotocin induced diabetic mice. Indian Journal of Natural Products and Resources, 2010 ; 1: 200-03.

10. Rathi Sre PR, Sheila T, Kandasamy M: Phytochemical screening and "in-vitro" anti-oxidant activity of methanolic root extract of Erythrina indica. Asian Pac J Trop Biomed, 2012 ; S 16961700 .

11. Udayan, PS.: Tinospora sinensis (Lour.) Merr. From sickupara, kollohills forest, Namakkal District Tamilnadu. Zoo's Print Journal 2004, 19 (9): 1622- 1623.

12. Singleton V L., Rossi J A: Colorimetry of total phenolics with Phosphomolybdic-phosphotungstic acid reagents. Am.J.Enol.Vitic., 1965 ; 16: 144-158.

13. Ordonez AAL, Gomez J G, Vattuone M A, Isla M I: Antioxidant activities of Sechium edule (Jacq.) Swart extracts. Food Chem., 2006; 97: 452-458.

14. Kumaran A, Karunakaran R J: Antioxidant and free radical scavenging activity of an aqueous extract of Coleus aromaticus. Food Chem., 2006 ; 97: 109-114.

15. Oyaizu M: Studies on product on browning reaction prepared from glucose amine. Jpn. J. Nutr., 1986; 44: 307-315.

16. Blois M S: Antioxidant determination by the use of of a stable free radical. Nature, 1958 ; 181: 1199-1200.

17. Re R, Pellegrini N, Proteggente A, Pannala A, Yang M, Rice-Evans C: Antioxidant activity applying an improved ABTS radical cation decolorization assay. Free Radical Bio Med., 1999; 26: 1231-1237. 
18. Ali H, Houghton PJ, Soumyanath A: $\alpha$ - Amylase inhibitory activity of some Malaysian plants used to treat diabetes; with particular reference to phyllanthus amarus. J Ethnopharmacol, 2006; 107: 44955.

19. Kim JS, Hyun TK, Kim MJ: The inhibitory effects of ethanol extracts from sorghum, foxtail millet and proso millet on $\alpha$-glucosidase and $\alpha$-amylase activities. Food Chem., 2011; 124: 1647-51.

20. Shai LJ., Masoko P, Mokgotho MP, Magano SR, Mogale MA, Boaduo N, Eloff JN. Yeast alpha glucosidase inhibitory and antioxidant activities of six medicinal plants collected in Phalaborwa. South African J. Bot., 2010; 76: 465470.

21. Chandrashekharaiah KS, Menaka N Bolaki, Gupta Shivani Sanjay, Aanchal Bathija, Murthy VK, Narayanaswamy M, Swamy NR: Anti-oxidant and Anti-hyperglycemic Properties of Methanolic Extracts of Medicinal Plants. Biosci., Biotech. Res. Asia, 2013; 10(2): 607-612.

22. Florence $\mathrm{O} \mathrm{J}$, Adeolu A A, Anthony $\mathrm{J}$ A: Comparison of the nutritive value, antioxidant and antibacterial activities of Sonchus asper and Sonchus oleraceus Rec. Nat. Prod., 2011; 5 (1): 29-42.

23. Pourmorad F, Hosseinimehr S J, Shahabimajd N: Antioxidant activity, phenol and flavonoid contents of some selected Iranian medicinal plants. Afr. J. Biotechnol., 2006; 5(11): 1142-1145.
24. Koleva I I, Van Beek TA, Linssen J P H, Groot A D, Evstatieva LN: Screening of plant extracts for antioxidant activity: a comparative study on three testing methods. Phytochem. Anal., 2002; 13: 8-17.

25. Mai TT, Thu NN, Tien PG, Van Chuyen N: Alpha-glucosidase inhibitory and antioxidant activities of Vietnamese edible plants and their relationships with polyphenol contents. J Nutr Sci Vitaminol (Tokyo), 2007, 53: 267-76.

26. Ramkumar KM., Thayumanavan B, Palvannan T, Rajaguru P. Inhibitory effect of Gymnema Montanum leaves on $\alpha$-glucosidase activity and $\alpha$-amylase activity and their relationship with polyphenolic content. Medicinal Chemistry Research, 2010; 19(8): 948-961.

27. Manikandan R, Vijaya A, Muthumani GD: Phytochemical and in vitro anti-diabetic activity of methanolic extract of Psidium guajava leaves. International Journal of Current Microbiology and Applied Sciences, 2013; 2(2):15-19.

\section{How to cite this article:}

Banerjee A, Maji B, Mukherjee S, Chaudhuri K, Seal T. In Vitro Antidiabetic and Anti-oxidant Activities of Methanol Extract of Tinospora Sinensis. J App Biol Biotech. 2017; 5 (03): 061-067. 